\title{
COVID-19: comprehensive review on mutations and current vaccines
}

\author{
Ananda Vardhan Hebbani ${ }^{1} \cdot$ Swetha Pulakuntla ${ }^{2}$ Padmavathi Pannuru ${ }^{3} \cdot$ Sreelatha Aramgam ${ }^{2,4}$. \\ Kameswara Rao Badri ${ }^{5,6} \cdot$ Vaddi Damodara Reddy ${ }^{2}$ (])
}

Received: 3 August 2021 / Revised: 9 November 2021 / Accepted: 22 November 2021 / Published online: 6 December 2021

(c) The Author(s), under exclusive licence to Springer-Verlag GmbH Germany, part of Springer Nature 2021

\begin{abstract}
Viral outbreaks had been a threat for the human race for a long time. Several epidemics and pandemics have been reported in the past with serious consequences on human health and subsequent social and economic aspects. According to WHO, viral infections continue to be a major health concern globally. Novel coronavirus, SARS-CoV-2 (Severe acute respiratory syndrome coronavirus-2) causes the most recent infectious pandemic disease, COVID-19 (Coronavirus disease-19). As of now, there were 249 million infections of COVID-19 worldwide with a high mortality of more than 5 million deaths reported; and the number of new additional cases is drastically increasing. Development of therapies to treat the infected cases and prophylactic agents including vaccines that are effective towards different variants are crucial to curtail the COVID-19 pandemic. Owing to the fact that there is a high mortality and morbidity rate along with the risk of virus causing further epidemic outbursts, development of additional effective therapeutic and preventive strategies are highly warranted. Prevention, early detection and treatment will reduce the spread of COVID-19 pandemic. The present review highlights the novel mutations and therapeutic updates associated with coronaviruses along with the clinical manifestations—diagnosis, clinical management and, prophylactic and therapeutic strategies of COVID-19 infection.
\end{abstract}

Keywords SARS-CoV-2 $\cdot$ Mutations $\cdot$ COVID-19 $\cdot$ Clinical management $\cdot$ Therapeutic strategies

Communicated by Erko Stackebrandt.

Ananda Vardhan Hebbani and Swetha Pulakuntla contributed equally.

Kameswara Rao Badri

kbadri@msm.edu

Vaddi Damodara Reddy

damodara.reddyv@ reva.edu.in

1 Department of Biochemistry, Indian Academy Degree College, Bengaluru 560 043, India

2 Department of Biochemistry, REVA University, Bengaluru 560064, India

3 DR Biosciences, Research and Development Institute, Bettahalasur, Bengaluru 562157, India

4 Department of Radiation Oncology, Emory University School of Medicine, Atlanta, GA 30322, USA

5 Department of Pharmacology and Toxicology, Cardiovascular Research Institute, Morehouse School of Medicine, Atlanta, GA 30310, USA

6 Clinical Analytical Chemistry Laboratory, Clinical Research Center, Morehouse School of Medicine, Atlanta, GA 30310, USA

\section{Introduction}

An incidence of unidentified pneumonia caused by 2019nCoV/SARS-CoV-2 (Severe Acute Respiratory Syndrome Coronovirus-2) was reported in the Wuhan city, China in the final months of 2019 (Zhou et al. 2020). The unidentified pneumonia was termed as COVID-19 (Coronavirus disease-19) considered to have spread from bats to humans. The mode of spreading from human to human is predominantly, through airborne respiratory droplet contact. The basic reproduction number $\left(R_{0}\right)$ of the virus is analyzed to be in between 1.4 and 6.47 across different countries, which is not just of wider range when compared to the other corona viral infections, but also stands at a position very near after the other well-known infectious diseases such as Measles, Chickenpox, Mumps, Polio and Rubella (Liu et al. 2020; Tang et al. 2020). Genetic and phylogenetic analysis revealed that SARS-CoV- 2 belongs to $\beta$-coronaviruses along with the other two predominant members, i.e., MERS-CoV (Middle East respiratory syndrome-related coronavirus) and SARS-CoV (severe acute respiratory syndrome coronavirus) (Leao et al. 2020). All the recent viral infection 
threat includes SARS of 2003 being caused by SARS-CoV, MERS of 2012 being caused by MERS-CoV and COVID19 of 2019 being caused by SARS-CoV-2; belongs to the same family, Coronaviridae (Gorbalenya et al. 2020). Over 20 different viral families are being clinically characterized for their disease causing potential and transmission pattern amongst which Coronaviridae family is being investigated quite significantly, but still a long way to go given the morbidity and mortality associated (Gorbalenya and Siddell 2021). Though initiated and appeared as a simple unidentified form of pneumonia, COVID-19 is one of the very few viral infections which transformed into a global pandemic in a very short span of time. Globally, the wavy pattern of COVID-19 infection and mortality rate is certainly attributable to the rate of its mutation and this review is an attempt to understand the same.

COVID-19 has a wavy pattern of infection / mortality rates, understanding the mutations and their associated epidemiology will be interesting.

\section{Viral lineage}

According to the Coronaviridae study group of Animal ssRNA + viruses subcommittee of the ICTV (International Virus Taxonomy committee), Coronaviridae is the largest family of Coronaviruses (CoVs) belongs to the suborder Cornidovirineae, order Nidovirales, phylum Incertae sedis and realm Riboviria. The Coronaviridae family has 2 subfamilies, 5 genera, 27 subgenera and 46 species, based on serologic and genetic analysis (de Groot et al. 2013; Pascarella et al. 2020). The detailed genetic lineages are presented in Figs. 1 and 2. There are similarities either in the perspective of disease caused or viral receptor type/distribution amongst the human coronaviruses and the details are summarized in Table 1.

\section{Structure and epidemiology of SARS-CoV-2}

CoVs are roughly spherical, moderately pleomorphic and a typical virion has been reported to be of an average diameter of 80-125 nm, enveloped, with single stranded positive (-sense) RNA viruses with a nucleocapsid. The RNA genome is of $26-32 \mathrm{~kb}$ in size with 7-10 translatable ORFs (open reading frames). ORF1a and $\mathrm{b}$ are translated into proteins, pp1a and pp1ab (polyprotein 1a and 1ab). These polyproteins will be processed by viral proteases to synthesize 16 non-structural proteins. Among those, RNA-dependent RNA-polymerase enzyme (RdRp) is one that aids in replicating viral RNA through transcription of a minus strand template, during which CoVs generate 6

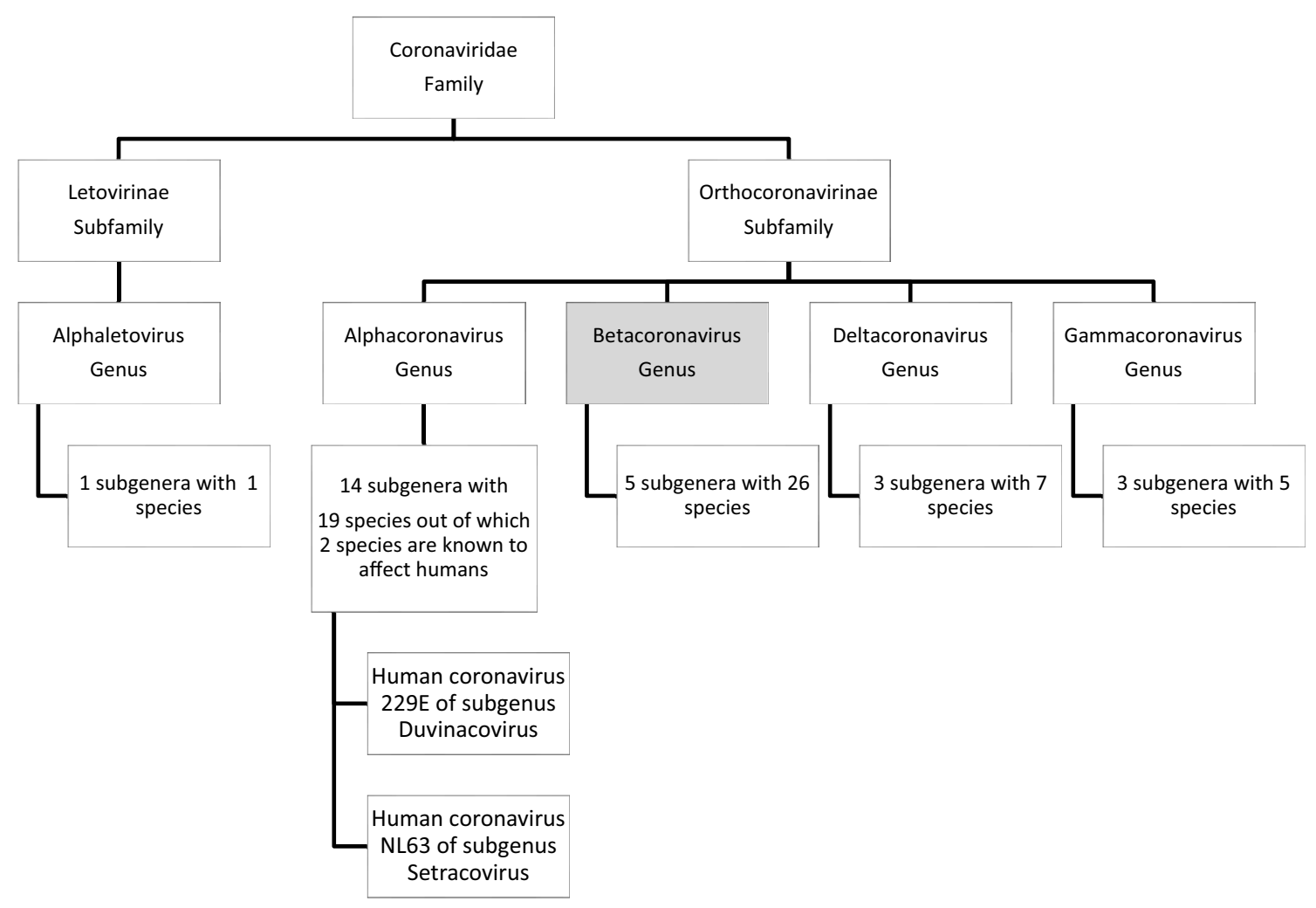

Fig. 1 Genetic lineage of Corona family 


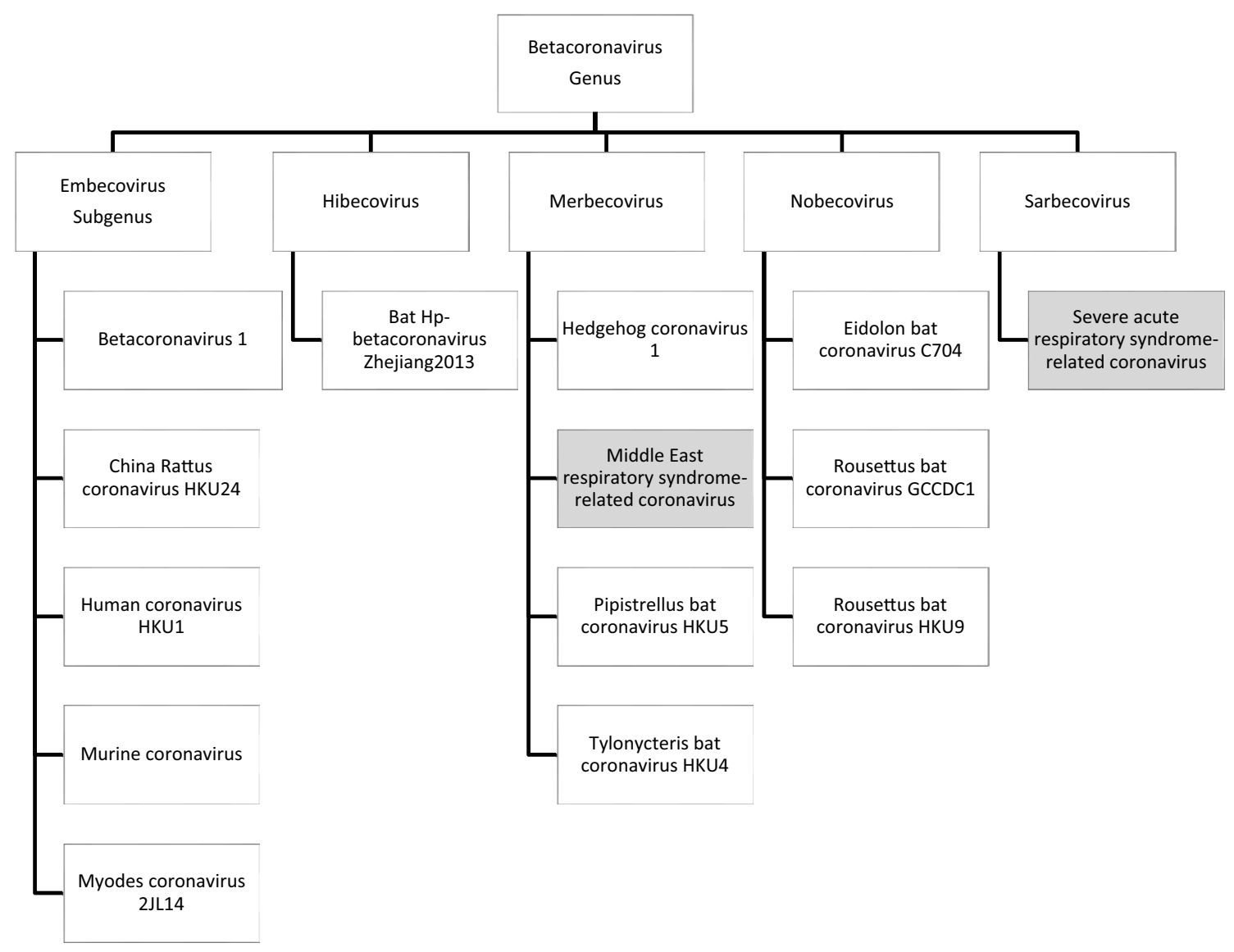

Fig. 2 Genetic lineage of Corona viruses

Table 1 Comparison of the viral host receptor and its distribution in humans

\begin{tabular}{|c|c|c|c|}
\hline Human disease & Corona virus & Viral host receptor & Receptor distribution in the body \\
\hline Mild respiratory infections & HCoV-NL63 & ACE2 & $\begin{array}{l}\text { Epithelial lining in nose, mouth and lungs } \\
\text { Also in heart, blood vessels, kidneys, liver and GI tract }\end{array}$ \\
\hline Mild respiratory infections & HCoV-229E & ANPEP & $\begin{array}{l}\text { Small intestine, renal microvillar membrane and other } \\
\text { plasma membranes }\end{array}$ \\
\hline Mild respiratory infections & $\mathrm{HCoV}-\mathrm{OC} 43$ & 9-O-Ac-Sia & Unknown \\
\hline Mild respiratory infections & HCoV-HKU1 & 9-O-Ac-Sia & Unknown \\
\hline Mild respiratory infections or SARS & SARS-CoV & ACE2 & $\begin{array}{l}\text { Epithelial lining in nose, mouth and lungs } \\
\text { Also in heart, blood vessels, kidneys, liver and GI tract }\end{array}$ \\
\hline Mild or severe MERS & MERS-CoV & DPP4 & Epithelial lining of lungs and kidneys \\
\hline Mild or severe COVID-19 & SARS-CoV-2 & ACE2 & $\begin{array}{l}\text { Epithelial lining in nose, mouth and lungs } \\
\text { Also in heart, blood vessels, kidneys, liver and GI tract }\end{array}$ \\
\hline
\end{tabular}

to 9 sub-genomic mRNAs (sgmRNAs) that help in translation of the accessory and structural proteins from the downstream ORFs. Viral genome also codes for all the necessary viral structural and functional proteins (viral infection and replication) including envelope protein $(\mathrm{E})$, nucleocapsid protein $(\mathrm{N})$, membrane protein $(\mathrm{M})$ and spike protein (S) (Ahn et al. 2020).

\section{Mutation types and frequency in SARS-CoV-2 genomes}

We have reported different global mutations of SARSCoV-2 presented globally during Dec 2019 to June 2021. This data were collected from multiple resources including 
PubMed (https://pubmed.ncbi.nlm.nih.gov/), Genbank (https://www.ncbi.nlm.nih.gov/genbank/) database and GISAID (https://www.gisaid.org/) genomic database. In this review, we have reported maximum number of identified mutations; non-synonymous, synonymous, point mutations, deletions, and silent mutations of the whole genome from multiple sources and the data are presented in Table 2.

Non-structural proteins of the coronavirus wholegenome encodes 6 ORFs, the largest occupied by ORF1ab polyproteins which can produce the 16 non-structural proteins (nsps) that are important for the viral replications. NSPs has the highest number of missense mutations in the ORF1ab region found in 1905 mutations. Out of total mutations 3328, 1344 are synonymous mutations 57 are deletion mutations, 2 are insertion mutations, 7 are frame shift deletion mutations, and 13 are stop-gained (Koyama et al. 2020). The most frequent mutations E191G, G76S, K61N, V259L, T176I, L140V, T269M and V88L are in the ORF region. We have reported multiple mutations in nsp, RdRp including P323L and 11 deletions in the conserved region that may be useful for the drug target for antiviral drugs (Yang et al. 2020).

Table 2 Global SARS-CoV-2 viral mutations

\begin{tabular}{|c|c|c|}
\hline Country & Mutations & References \\
\hline India & $\begin{array}{l}\text { D614G, P323L, G1124V, R203K and G204R, Q271R, R78M, E583D, L54F, } \\
\text { K77M, A520S, A706S, G1251V, T22I, E471Q, S494P, G1124V, Q271R, } \\
\text { L5F, F2L, G261S,M177I, L7I, E156D, S162I, T572I, Q6771H, L18F, } \\
\text { E224G, A243S, T299I, P82L, D290Y, K558N, D574H, R634S, I402L, } \\
\text { Y28H, T274I, T323I, T1027I, H49Y, T602I, A879S, V1104L, P1263L, } \\
\text { M731R, F797C, T761S, L828P, A831S, G857C, A930T, H1101Y, K1191N, } \\
\text { A771V,T1027I, C1243F, G769V, C1250F, G125V, V1068V, S1021F, A892V }\end{array}$ & $\begin{array}{l}\text { Maitra et al. (2020); Baner- } \\
\text { jee et al. (2020) }\end{array}$ \\
\hline $\begin{array}{l}\text { Worldwide (Europe, China, } \\
\text { North America, Asia, South } \\
\text { America) }\end{array}$ & $\begin{array}{l}\text { S-protein:D614G,L752F, F32I, H655Y, V483A, F157L, V615L, K202N, } \\
\text { S939F, F797C, A930V, R408I, V367F, Q409E, S254F, A435S, D1146E, } \\
\text { S247R and P1143L } \\
\text { ORF Region:E191G, G76S, K61N, V259L, T176I, L140V, T269M and V88L } \\
\text { N: K247I, S194L, P46S, S327L, E378Q, and D343V } \\
\text { ORF8:T11I, L84S, S97N, and S67F } \\
\text { ORF7a: P34S, Q62*, and H73Q } \\
\text { ORF10: P10S and I13M } \\
\text { E:S6L }\end{array}$ & Yang et al. (2020) \\
\hline Globe wise & $\begin{array}{l}\text { Non-Synomous:L84S, D614G, G251V, P214L, R203K, G204R, Q57H, } \\
\text { N679Y, S680P, Q677H, Q675H, T175M and D3G } \\
\text { Synonymous: D467V, I468F, I468T, I472V, G476S, S477G, V483A, P491R, } \\
\text { Y508H, R509K and V510L }\end{array}$ & Kim et al. (2020) \\
\hline Multiple countries & $\begin{array}{l}\text { L54F, A27V, T29I, H49I, H49Y, E96D, D111N, T240I, G176V, A348T, } \\
\text { G476S, V483A, A520S, H519Q, D614G, D936Y, A1078V and D1259H, } \\
\text { F106F, P314L, Q57H, G203K\&R, T85I,L37F, Y446Y, G251V, S76S, L84S, } \\
\text { L7L, M54K, P504L, P585S, I559V, R337R, D268*, G212D,S247R, V378I, } \\
\text { L84S, G392D, A376T, P334S, L3606F, G251V }\end{array}$ & Mercatelli and Giorgi (2020) \\
\hline India & $\begin{array}{l}\text { T19R, K77T, T95I, G142D, E154K, N440K, L452R, T478K, E484Q, D614G, } \\
\text { P681R, D950N, Q1071H, H1101D }\end{array}$ & Cherian et al. (2021) \\
\hline China & $\begin{array}{l}\text { F2L, Q14S, V16L, T29S, K41T, V42I, S46N T51S, D53G, F59Y, I62L, S65N, } \\
\text { F73V, N81K, V84I, S91A, I101V, T114S, V127I, E132N, F140Y, Q173K } \\
\text { L176M, M177L, L179M, Q183S, K187D, N188T, I210V, N211D, L212V, } \\
\text { D215N, D228E, L229I, R237K, Q239R, A243T, L244I, A262S, L276M, } \\
\text { E281Q, A292S, T299A, F306L, T345S, A371T, I402V, R403K, N440K, } \\
\text { S443A, V445T, G447D, N460K, A61T, N68G, R72K, K147N, S151T, } \\
\text { F489Y, Q492E, Q497H, N500T, G503N, Y507F, H528N, A520G, V171I, } \\
\text { I197V, N531T, N555K, K557Q, A569S,D614G V 622M, D627E,T632A, } \\
\text { T638A, S640A I651V, I666V, Q675H, T676S, T678S, S708A, L752F, } \\
\text { A1078T, G1093A S221A, S255E, A260T, K278S, S689Q, Q690R, V1104I, } \\
\text { V1228I }\end{array}$ & Pulakuntla et al. (2021) \\
\hline RUSSIA & D138H, D614G & \\
\hline ITALY & L5F, Q239K, D614G, T630S & \\
\hline USA & L5F, V367F, D614G, A892S & \\
\hline
\end{tabular}




\section{Mutations associated with coronavirus structural proteins}

\section{Spike Glycoprotein mutations}

The spike (S) region is a large multifunctional and transmembrane protein. In spike protein, the receptor-binding domain (rbd) has an affinity to bind with ACE2 (Angiotensin-converting enzyme 2) of the host cells and facilitates the corona viral entry into the host cell, leading to the rapid transmission for the infection of the SARS-CoV-2. Comparison of various global strains with Wuhan sequence revealed 394 missense mutations, 260 synonymous, 5 deletions 1 framshift and 1 stop-gained 6 overall all mutations in spike region 687 (Yang et al. 2020). Among the two sub-regions of spike protein, S1 and S2 domain, the S1 domain having the highest number of mutations D614G, Y28H, H49Y, R78M, K77M, Q271R, T22I G261S, E471, S494, A520S and I402L responsible for the pathogenicity of the SARS-CoV-2 (Maitra et al. 2020; Pulakuntla et al. 2021). Our studies also identified high-frequency combination mutations like D614G + I472V, D614G + K458R, $\mathrm{D} 614 \mathrm{G}+\mathrm{V} 341 \mathrm{I}, \mathrm{D} 614 \mathrm{G}+\mathrm{Q} 675 \mathrm{H}, \mathrm{D} 614 \mathrm{G}+\mathrm{Q} 675 \mathrm{H}$, $\mathrm{D} 614 \mathrm{G}+\mathrm{S} 939 \mathrm{~F}, \mathrm{D} 614 \mathrm{G}+\mathrm{D} 936 \mathrm{Y}$ and $\mathrm{D} 614 \mathrm{G}+\mathrm{L} 5 \mathrm{~F}$ are responsible for increased infectivity ( $\mathrm{Li}$ et al. 2020). This may potentially reorganize $S$ protein with loss of hydrogen bonds with adjacent residues there by enhancing binding of S1 region with ACE2 enhancing viral entry and host to host transmission. These mutations and these areas of spike protein must be investigated. The D614G is a strong non-synonymous mutation along with these few other frequent mutations in the S region including L84S, D614G, G251V, P214L, R203K, G204R, Q57H, N679Y, S680P, Q677H, Q675H, T175M and D3G. Out of these 11 mutations, V510L, R509K, Y508H, P491R, V483A, S477G, G476S, I472V, I468T, I468F and D467V are synonymous and located near to ACE2 receptor binding site (Pulakuntla et al. 2021). The association of V483H and G476S mutations on human ACE2 receptor binding capacity in MERS and SARS research have been demonstrated (Cherian et al. 2021). Novel mutations of SARS-CoV-2 started showing up leading to the second wave of infections during December 2020 to March 2021. Among these most frequent triple mutations are T19R, K77T, T95I, G142D, E154K, N440K, T478K, E484Q, D614G, P681R, D950N, Q1071H and H1101D (Cherian et al. 2021).

Aforementioned D614G mutations are generally associated with B.1 lineage of viruses, which has many sublineages and all of them are established to show multiple changes in spike proteins. The sublineage B.1.617.2 lineage is referred to as SARS-CoV-2 Delta variant, which has been the latest mutational variant observed globally (Planas et al. 2021).

\section{SARS-CoV-2 variants and Delta variant}

There are multiple SARS-CoV-2 variants that include Alpha (B.1.1.7, Q.1-Q.8), Beta (B.1.351, B.1.351.2, B.1.351.3), Delta (B.1.617.2, AY.1, AY.2, AY.3), Gamma (P.1, P.1.1, P.1.2), Epsilon (B.1.427, B.1.429), Eta (B.1.525), Iota (B.1.526), Kappa (B.1.617.1), 1.617.3, Mu (B.1.621, B.1.621.1), Zeta (P.2), Lambda (C.37). b.1.1.7 and Q lineages (alpha), B.1.351, B.1.351.2, B.1.351.3 (beta), B.1.617.2, AY.1, AY.2, AY.3 (delta) and P.1. P.1.1, P.1.2 (gamma) were categorized initially as variants of concern based on increases transmissibility and increased disease severity and evidence of impact on diagnosis, treatment and protectiveness against vaccines. Even though, Alpha, Beta, Gamma and Epsilon variants were categorized variants of concern until recently, but now they were categorized as variants being monitored (VM). The other variants that fall under VM are Eta, Iota, Kappa, B.1.617.3, Zeta and Mu.

B.1.427, B.1.429, B.1.525 (Eta), B.1.526 (Iota), B.1.617.1 (kappa) and B.1.616.3 were categorized by Center for Disease Control as variants of interest (VI) until recently however based on latest developments currently there are no variants under VI category. Until recently there were no SARS-CoV-2 variants higher than the prior category (VI) that falls under variants of high consequence $(\mathrm{VH})$ category. However, Delta (B.1.617.2 and AY lineages) were categorized under this group recently based on increased transmissibility, increased disease severity and evidence of impact of diagnosis, treatment and/or vaccine (https://www.cdc.gov/ coronavirus/2019-ncov/variants/variant-info.html).

SARS-CoV-2 B.1.617.2 also termed as delta variant was reported to have got identified in October 2020 predominantly in India and further supposed to have spread to the UK and many other countries by December 2020. SARSCoV-2 Delta variant is one among the three major subtypes viz., B1.617.1, B1.617.2 and B1.617.3 which contain mutations predominantly in the $\mathrm{N}$-terminal and the receptor binding domains of S-proteins. Since mutations are associated with S-protein (T19R, V70F*, T95I, F142D, E156-, F157-, R158G, A222V*, W258L*, K417N*, L452R, T478K, D614G, P681R, D950N) in delta variant is understood to be much more infectious with very fast rate of infectivity when compared to other variants. Thus, SARS-CoV-2 Delta variant is being classified as variant of concern (VOC) by Centres for Disease Control and Prevention (CDC), USA; with enhanced $(>60 \%)$ transmissibility potential in comparison to the other variants (Planas et al. 2021).

\section{Envelope (E) protein mutations}

Corona envelope protein is the smallest and important structural protein key in the assembly and budding of the virus. Deletion of E-protein led to attenuated virus production. The 
membrane peptide works as a viroporin and inactivation or lack of this protein, the structural changes can take place in the virus leading to transmission. It has three domains, C-terminal domain (functional), amino-terminal (hydrophobic) and transmembrane domain (hydrophobic). The E-protein of SARS-CoV-2 is being considered as one of the highly conserved proteins. E protein has a limited number of mutations while comparing with other proteins and about 43 synonymous and missense mutations were reported (Koyama et al. 2020). Studies showed that enhanced amino acid variations were observed in the C-terminal domain of the $\mathrm{E}$ protein that were playing a key role in COVID-19 pathogenesis (Rahman et al. 2021). Transmembrane domain mutation (V25A) and many triple cysteine motif harbouring mutations (L39M, A41S, A41 V, C43F, C43R, C43S, C44Y and $\mathrm{N} 45 \mathrm{R}$ ) are being reported as the major variants of $\mathrm{E}$ protein mutations, which control conformational and binding characteristics of E-protein (Rahman et al. 2021). Though highly conserved, the observed mutations in $\mathrm{E}$ protein have got a lot of biological relevance and importance, especially to design a therapeutic intervention.

\section{- Membrane (M) protein mutations}

Membrane viral protein of the coronavirus is the most abundant envelope protein of coronaviruses. M-Protein play a key role in viral assembly, morphogenesis and antigenecity. It shapes the envelope and it could bind with nucleocapsid and be involved in coronavirus assembly. It has three transmembrane domains, with an amino terminus (short) that projects out and c-terminus (long) that projects inside of the virus. In silico studies reported that the M-protein of SARS$\mathrm{CoV}-2$ is $>98 \%$ similar to that of bat and pangolin SARS$\mathrm{CoV}$, which demonstrates its evolutionarily conserved nature (Thomas 2020). Though relatively uncommon, M protein gene mutations are being newly observed especially in the USA patient pool, which is reported to be the reason behind the hike in the number of COVID positive cases (Shen et al. 2021). Emergence of novel M182T and V70L are being reported across the globe and the present evidence suggests that so far 71 synonymous mutations associated with $\mathrm{M}$ gene are being identified (Koyama et al. 2020). Mutations associated with $\mathrm{M}$ proteins seem to be more alarming because of the observation that the average age of the patient pool associated with M mutation is 4.6-6.3 years (Shen et al. 2021).

\section{Nucleocapsid protein mutations}

The nucleocapsid protein is multifunctional majorly facilitates genome packing and assembles the viral RNA with membrane proteins. It can enhance the transcription efficiency of the virus. $\mathrm{N}$ protein has conserved $\mathrm{N}$-terminal and $\mathrm{C}$-terminal domains. $\mathrm{N}$-protein also modulates the antiviral function as an antagonist to interferon the host response. $\mathrm{N}$ protein of SARSCoV showed frequent mutations, P46S, S194L, K247I, S327L, D343V and E378Q. Koyama et al. (2020) reported a total of 378 mutations out of which 246 are missense mutations, 126 are synonymous mutations and 6 deletion mutations viz., ORF3a, ORF6, ORF7, ORF8 and ORF10 of the viral genome have relatively fewer mutations, i.e., 344 missense mutations, 149 synonymous, 9 deletion, 3 frame shift mutations and 17 stop-gained mutations compared to other proteins.

\section{Mutations associate with other non-structural (nsp) and accessory proteins}

The SARS-CoV-2 genome has 15 non-structural proteins nsp1-10 and nsp12-16 (total 16 nsps including nsp11) along with 8 auxillary protein ORF3a, ORF3b, ORFp6, ORF7a, ORF7b, ORF8b, ORF9b and ORF14. These proteins play a key role in viral amplification. Mutations in these auxiliary/accessory proteins were not found so far (Banerjee et al. 2020; Kim et al. 2020; Mercatelli and Giorgi 2020; Wu et al. 2020). It is important to verify for and analyze these mutations to understand the pathogenicity and to improve the host immunity. SARS-CoV-2 mutational data were collected from existing literature as well as our lab reports.

\section{Diagnosis}

According to WHO, diagnosis of COVID-19 infection at appropriate time after initial observation of symptoms play a crucial role in the control of pandemic. As of now, many commercial kits are available using nasal, nasopharyngeal and saliva samples. In India, multiple kits were available using saliva swab samples including $\operatorname{IgG} / \operatorname{IgM}$ antibodies by myLAB Box, gold nanoparticles-based colorimetric detection kit by Oxford Suzhou center for advanced research and gold nanoparticles coated with glucans-based colorimetric detection by Iceni Diagnostics (Amawi et al. 2020). Additionally, real-time PCR amplification of viral E gene assay confirmatory testing and RdRp/nsp7-8-12 gene assay, based on collection of respiratory samples from hospitalized patients is also being developed and used for the detection of COVID-19 (Corman et al. 2020). Globally various PCRbased (single gene and multiple gene amplification, realtime based, LAMP based) and antigen-antibody interactionbased assays are available using various clinical samples.

\section{Clinical manifestations}

As SARS-CoV can infect all the general population in various ways, infection rate can be classified into mild, moderate and severe. Mild and moderate infections are with asymptomatic and/or few symptoms (fever, cold, dry 
Cough, tiredness, headache, pains, loss of smell and taste) and potentially get cured by home isolation (da Rosa et al. 2021). In case of severe infections of COVID due to high viral titers that leads to hypoxia especially in individuals with co-morbidities like obesity, diabetes, cardiovascular and neurological diseases. There are 27 clinical manifestations and few were summarised in Table 3. Vahey et al. 2020 reported that COVID-19-infected patients symptoms like fever, cough, malaise, dyspnoea, fatigue, sputum/secretion, dermatological manifestations, anorexia, sneeze, neurological, symptoms, rhinitis, myalgia, goose bumps, sore throat, headache, diarrhoea, chest pain, rhinorrhoea, palpitation, dizziness, nausea or vomiting, shivering, confusion, nasal congestion, nasal congestion, abdominal pain and haemoptysis. Clinical manifestation that presented in the highest number $(58 \%)$ of infected patients was fever followed by cough $(55 \%)$. Neurological symptoms (20\%) are also other main clinical manifestations causing anosmia and hyposmia, mechanism/s of which are poorly understood. At present, most of the cases are suffering from respiratory diseases and it is difficult to identify and differentiate respiratory problems from COVID. To identify the respiratory disease clinical manifestations of COVID-19 are helpful to characterize COVID-19 (da Rosa et al. 2021).

\section{Therapeutic strategies}

Sheahan et al. (2020) report describes the clinical protocols for the diagnosis and treatment of COVID-19, in which many therapeutic strategies to treat COVID-19 are being mentioned. The strategies predominantly include convalescent plasma therapy, circulatory and blood purification support, antiviral therapy, oxygen therapy, mechanical ventilation (invasive), immunotherapy, rescue therapy, renal replacement/transplant, and additional treatment options including usage of traditional medicines. Studies have shown that SARS-CoV-2 viral loads are significantly comparable to the disease intensity and progression (Horby et al. 2021), which highlights the importance of having a therapeutic strategy not only to treat the symptoms of infection, but also to be able to deal with the reduction in the viral loads. Known anti-viral and other drugs including remdesiver, IFN- $\alpha$, Lopinavir/ritonavir, Ribavirin, Chloroquine phosphate and hydroxychloroquine along with azithromycin and Arbidol, were used initially that were claimed to have a encouraging response in the preliminary treatment of COVID-19 (Vahey et al. 2020; Cyranoski 2020; Shen et al. 2020; Dong et al. 2020; McKee et al. 2020; Lai et al. 2020; Gautret et al. 2020). Later many research groups and pharmaceutical giants throughout the world started researching extensively on development of more specific therapeutic strategies to curtail COVID-19 infection and spread (Alijotas et al. 2020). Recently in India, the Drug Controller General of India approved the drug 2-Deoxy D-Glucose (2-DG), for emergency usage for moderate to severe COVID-19 patients (Verma et al. 2020). Besides, many candidate drugs viz., baricitinib, fedratinib, and ruxolitinib, JAK-STAT signaling inhibitors were being proposed to deal with elevated levels of cytokines during the infection (Stebbing et al. 2020). Parallel, due to the global demand for development of a permanent cure to the problem, many vaccines, drug and immunotherapeutic candidates were being proposed which started making their way into the clinical trials, the current status of which are being summarized in Tables 4 and 5 . Moreover, vaccines are the most effective prophylactic/therapeutic strategies for the protection of global health (Cunningham et al. 2020). Since passive immunization had been successfully used to treat infectious diseases, convalescent plasma therapy was anticipated to show effective therapeutic potential in treating COVID-19 it became one of the treatment options initially (Lai et al. 2020). Moreover, immediate

Table 3 Clinical manifestations of the COVID-19

\begin{tabular}{|c|c|c|c|}
\hline Disease category & Clinical features & $\begin{array}{l}\text { Clinical manifestations (may occur in } \\
\text { patients belonging to any of the last } \\
\text { three disease categories) }\end{array}$ & $\begin{array}{l}\text { Proportion } \\
\text { of patients } \\
\text { (Globally) }\end{array}$ \\
\hline Mild disease & Non/mild pneumonia & - & $75-85 \%$ \\
\hline Moderate disease & Pneumonia & \multirow{3}{*}{$\begin{array}{l}\text { Gastro intestinal symptoms such as } \\
\text { diarrhea and cramps; } \\
\text { Neurological symptoms such as } \\
\text { headache, altered mental status, } \\
\text { Guillain-Barre syndrome (GBS) } \\
\text { and Stroke; } \\
\text { Cardiovascular events such as } \\
\text { myocarditis, arrhythmias and heart } \\
\text { failure; } \\
\text { Ocular manifestations such as con- } \\
\text { junctival hyperemia, chemosis } \\
\text { Anosmia and dysgeusia }\end{array}$} & \\
\hline Severe disease & $\begin{array}{l}\text { Severe pneumonia, Dyspnea, Respiratory frequency } \geq 30 / \mathrm{min} \text {, Blood } \\
\text { oxygen saturation } \leq 93 \%, P / F \text { ratio }<300 \text {, Lung infiltrates }>50 \% \\
\text { (within } 24-48 \mathrm{~h} \text { ) }\end{array}$ & & $10-15 \%$ \\
\hline Critical disease & $\begin{array}{l}\text { Acute respiratory distress syndrome, Respiratory failure, Sepsis } \\
\text { (multiple organ dysfunction / failure) } \\
\text { Septic shock }\end{array}$ & & $5-10 \%$ \\
\hline
\end{tabular}




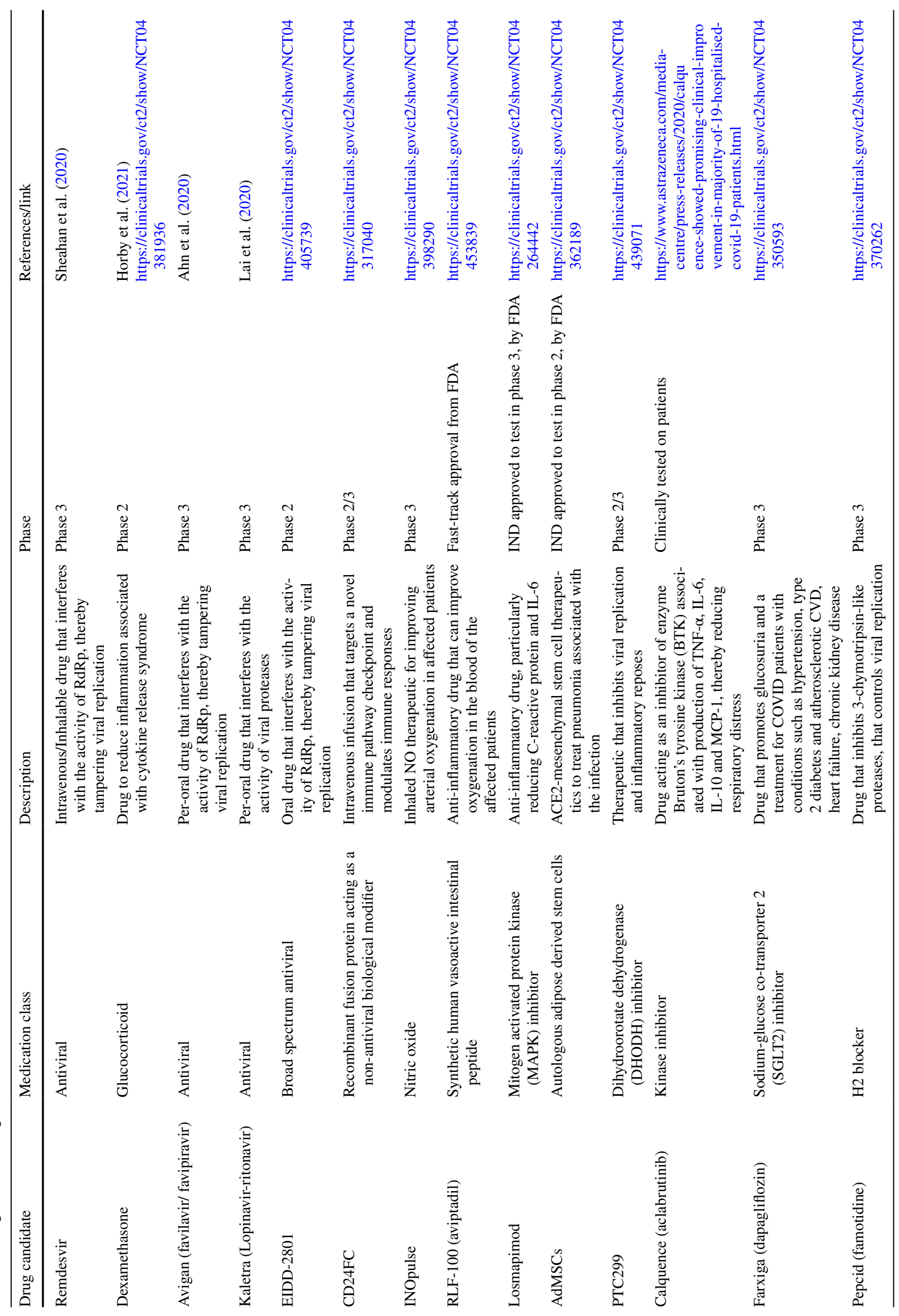


and simultaneous ambulatory and medical care along with randomized clinical trials is the only way to find effective and safe treatments for COVID-19 (Kalil 2020; Shree et al. 2020; Badri et al. 2021).

\section{Phytomedicine therapy}

By virtue of their multi-targeted and less toxic features, phytomedicines have attracted attention for prevention of many viral infections including COVID19. The increasing scientific proof of rich phytoconstituents in phytomedicine and ensuing treatment/prophylactic potentials have created remarkable confidence in the society (Girija and Sivan 2020). This led to a rise in confidence towards alternative traditional medicine. According to WHO reports, traditional medicine (TM) which includes Indian Ayurveda, Chinese medicine, and Arabic Unani medicinal therapies that use herbs/natural products are widely and rapidly growing health systems with plenty of economic advantage. Rich local traditional/cultural adaptations in countries like Belgium (38\%), China (40\%), USA (42\%), Australia (48\%), Canada (70\%), India (70\%), France (75\%) and Africa (80\%) are leaning more towards TM. In multiple geographical areas including Asia and Latin America, people prefer to use TM due to cultural beliefs and ancient traditions. TM is not only seen in developing and underdeveloped countries but in many developed countries it is increasingly accepted and growing rapidly. Potential of Ayurveda-based rasayana botanicals, which includes Withania somnifera, Tinospora cordifolia and Asparagus racemosus, in COVID-19 treatment is being postulated (Ang et al. 2020) using in-silico approaches by therapeutic potential of Ayurvedic preparations viz., Sudarshana Churna, Dhanvantara Gutika and Talisadi Churna along with proper diet and self-quarantining, in a selfdetected COVID-19 case is being reported by (DU et al. 2020). As per the Chinese and Korean guidelines, frequency of commonly used plant formulations for COVID-19 treatments is being extensively reviewed by use of traditional Chinese medicines in prevention of COVID-19 infection in healthy population and also treating the symptoms for patients at all stages of corona-viral/entero-viral infections were reported (Ren et al. 2020; Luo et al. 2020; Ni et al. 2020). Details of the different phytotherapeutic interventions that are being proposed/recommended/already attempted until now in literature to treat corona/entero viral infections in specific are being summarized in Table 6 .

\section{Current vaccines for COVID-19}

From January 2020, many studies and publications on SARS $\mathrm{CoV}-2$ whole genome sequences analysis and mutational analysis have been initiated and many are underway with spectacular collaborations among scientists from academia and multiple bio-pharmaceutical companies in the successful discovery and manufacture of various vaccines. According to WHO and the COVID-19 vaccine tracker, 74 vaccine candidates are being developed or under development worldwide. Among these few vaccines successfully completed 3rd phase trials and now those are in use and the data were shown in Table 7.

\section{mRNA Vaccines}

BNT162b2 BNT162b2 mRNA-based vaccine was developed by the Pfizer BioNtech, Fousun pharma. BioNtech is the first company to register for the FDA approval of their candidate COVID-19 vaccine. BNT162b2 is a lipid nanoparticle-based RNA vaccine (with nucleoside-modifications), encoding the SARS-CoV-2 full-length spike protein. Two proline mutations locks the spike protein confirmation in the prefusion conformation (Polack et al. 2020). After its development and testing, the vaccine has been designated to be administered in two doses, 21 days apart. After entry into the host cell, it makes multiple copies of viral full length spike protein through immune cells. It shows 95\% efficiency by encoding the viral spike protein for immune response. Total number of participants that participated in the study were 43,448 around the world (Sadoff et al. 2021). BNT162b2 administered doses have depended on neutralizing antibodies higher against the SARS-CoV-2. The significant immunogenicity and activation of the CD8+and CD4+T-cells was found (Clinical Trial id: NCT04368728).

mRNA-1273 mRNA-1273 COVID-19 vaccine is the first vaccine to be enrolled for clinical trials after complete SARS-CoV-2 genome sequencing and was developed by US-based start-up company, Moderna (Wang et al. 2021). mRNA-1273 is a novel lipid nanoparticle (LNP)-encapsulated mRNA-based vaccine that uses/delivers prefusion stabilized spike (S) protein of SARS-CoV-2. The mRNA translates to produce SARS-CoV-2 viral spike protein (full length), thereby allowing the body to generate an immune response and retain that information in memory immune cells. Efficacy shown in study participants who received the 2 doses of vaccine with negative baseline SARS-CoV-2 status, was approximately $94 \%$ for the follow-up period of 9 weeks. The data reviewed concludes that the benefits of mRNA-1273 vaccine outweigh the known and potential risks (Wu et al. 2021).

\section{Inactivated vaccine}

Covaxin (BBV152) India's first indegenous COVID19 vaccine BBV152/Covaxin was developed by Bharat Biotech in collaboration with Indian Council of Medical Research and National Institute of Virology. This vaccine used 


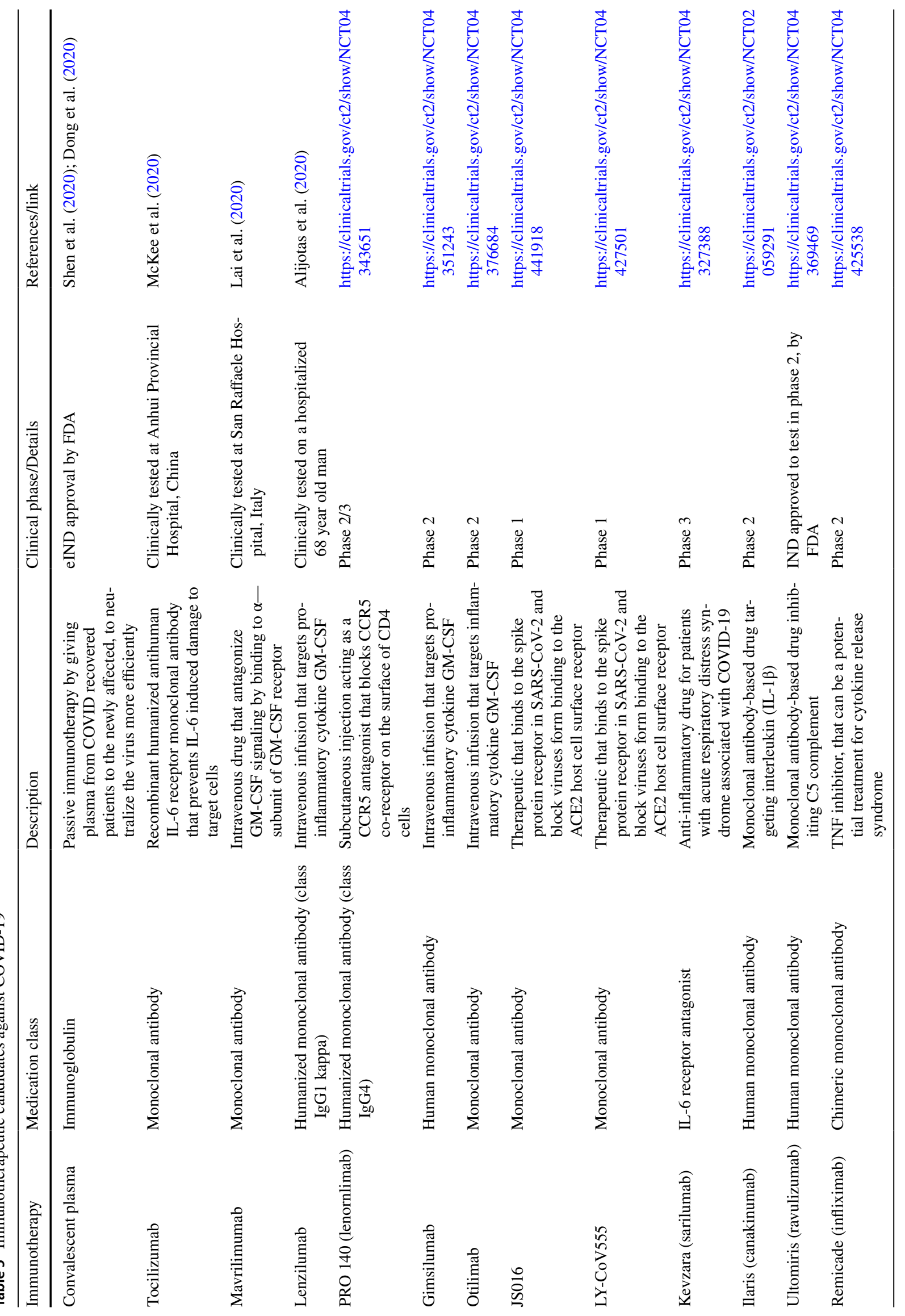




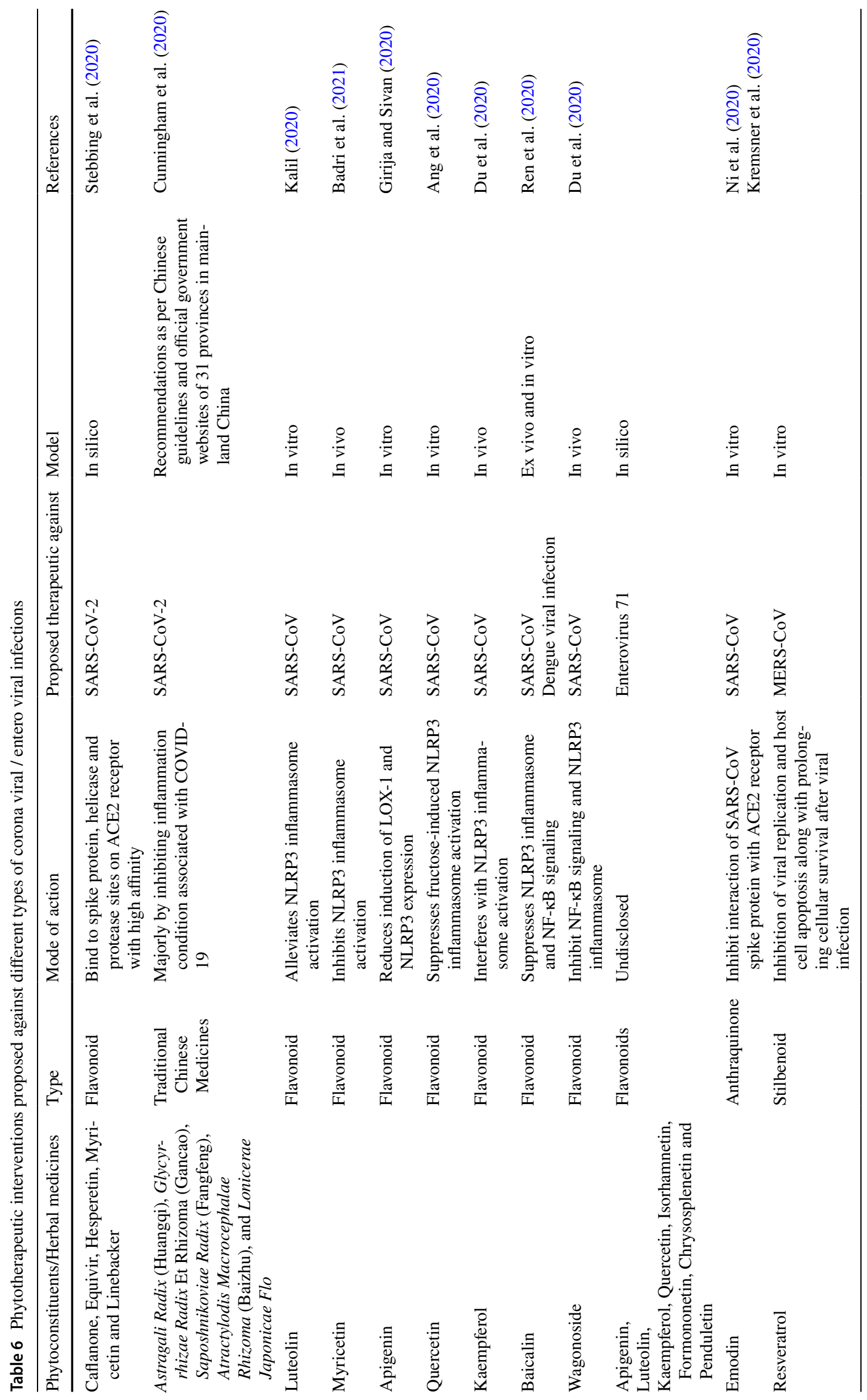


SARS-CoV2 whole-virion inactivated by $\beta$-propiolactone. The strain used, NIV-2020-770 contains the Asp614Gly mutation. It showed $50 \%$ efficiency with safe and immune response in the clinical trial with recruited 25,800 participants. However, the inactivation of SARS-CoV2 by $\beta$-propiolactone was reported to cause aggregation of the viral particles leading to loss of antigenic potential. This vaccine is also effective against the UK B.1.1.7 variants and specific to neutralizing IgG antibodies. The Drug controller general of India has approved after three phase clinical trials successfully present it has huge production in India (Ella et al. 2021).

CoronaVac CoronaVac COVID-19 Vaccine developed by Sinovac Biotech Ltd. is an inactivated pathogen. The virus is inactivated by $\beta$-propiolactone and then adjuvanted with aluminum hydroxide to make the vaccine, which is generally administered on a 0/14-28-day schedule to prevent the disease. This vaccine is also potent/protects against B.1.351, a South African variant and B.1.1.7, a UK variant. The resist- ance of the variants could be neutralized by this vaccine (Tanriover et al. 2021). As an assessment of the WHO's, the advisory group approved this vaccine for emergency use. The phase 3 clinical trials were conducted internationally on 9000 participants (clinical id: NCT04456595).

BBIBP-CorV BBIBP-CorV developed by Sinopharm, it is an inactivated vaccine. Study reports revealed that the vaccine have efficiencies upto $79.3 \%$ by neutralizing the antibodies with two doses after 21 days vaccination (Wang et al. 2020). This vaccine works the same as coronaVac and is made based on the UK strains, and WHO advised its usage only upon emergency. The sample size for this clinical trial was 1300 (Clinical id NCT04560881).

\section{Viral vectors}

AZD1222 The ChAdOx1 nCoV-19 vaccine (AZD1222) was developed at Oxford University. AZD1222 contains SARS-CoV-2 structural spike protein gene delivered by

Table 7 Current list of available vaccines and their efficiency

\begin{tabular}{|c|c|c|c|c|c|c|c|c|}
\hline S. no. & $\begin{array}{l}\text { Vaccine Name } \\
\text { clinical Trail id }\end{array}$ & $\begin{array}{l}\text { Devel- } \\
\text { oped } \\
\text { countries }\end{array}$ & Time line doses & $\%$ efficiency $(\%)$ & Ag type & Study evolution & Status & References \\
\hline 1 & $\begin{array}{l}\text { Pfizer (BNT162b2) } \\
\text { NCT04368728 }\end{array}$ & USA & $\begin{array}{l}21 \text { days b/w to } \\
\text { doses }\end{array}$ & 95 & mRNA & $\begin{array}{l}\text { Tolerability and } \\
\text { immunogenicity } \\
\text { from different } \\
\text { strain }\end{array}$ & In use & Polack et al. (2020) \\
\hline 2 & $\begin{array}{l}\text { Moderna } \\
\text { (mRNA-1273) } \\
\text { NCT04470427 } \\
\end{array}$ & USA & 28 days & 94 & mRNA & $\begin{array}{l}\text { Neutralization } \\
\text { against UK } \\
\text { variant strain } \\
\text { B.1.351varient }\end{array}$ & In use & Wu et al. (2021) \\
\hline 3 & $\begin{array}{l}\text { Covaxin } \\
(\text { BBV152) } \\
\text { NCT04471519 } \\
\end{array}$ & India & 28 days & 50 & In activated & $\begin{array}{l}\text { Neutralization } \\
\text { against UK vari- } \\
\text { ant strain }\end{array}$ & In use & Ella et al. (2021) \\
\hline 4 & $\begin{array}{l}\text { Covishiled } \\
\text { AZD1222 } \\
\text { NCT04516746 } \\
\end{array}$ & UK & 28 days & 65 & Viral vector & $\begin{array}{l}\text { Neutralization } \\
\text { against B.1.1.7 } \\
\text { variant }\end{array}$ & In use & Voysey et al. (2021) \\
\hline 5 & $\begin{array}{l}\text { Sputnik V } \\
\text { NCT04530396) }\end{array}$ & Russian & 21 days & 91 & Viral vector & Immune system & In use & $\begin{array}{l}\text { Jones and Roy } \\
\text { (2021) }\end{array}$ \\
\hline 6 & $\begin{array}{l}\text { Jassen (Johnson \& } \\
\text { Johnson) Ad26. } \\
\text { CoV2.S } \\
\text { NCT04505722 }\end{array}$ & USA & 28 days & 66 & Viral vector & $\begin{array}{l}\text { Effective against } \\
\text { severe condition }\end{array}$ & In Use & Sadoff et al. (2021) \\
\hline 7 & $\begin{array}{l}\text { Corona Vac } \\
\text { NCT04456595 }\end{array}$ & China & 14 days & 50.4 & Inactivated & $\begin{array}{l}\text { Effective against } \\
\text { UK, South Afri- } \\
\text { can variants }\end{array}$ & In use & Wang et al. (2021) \\
\hline 8 & $\begin{array}{l}\text { BBIBP } \\
\text { NCT04560881 }\end{array}$ & China & 21 days & 79.3 & Inactivated & $\begin{array}{l}\text { Variant neutraliza- } \\
\text { tion }\end{array}$ & In use & Wang et al. (2020) \\
\hline 9 & $\begin{array}{l}\text { EpiVacCorona } \\
\text { NCT04527575 } \\
\end{array}$ & Russia & 21 days & 90 & Peptide & $\begin{array}{l}\text { Increased immune } \\
\text { response }\end{array}$ & In use & $\begin{array}{l}\text { Doroftei et al. } \\
\text { (2021) }\end{array}$ \\
\hline 10 & $\begin{array}{l}\text { Convidecia } \\
\text { NCT04526990 }\end{array}$ & China & 21 days & 65 & Viral Vector & $\begin{array}{l}\text { Tolerability and } \\
\text { immunogenicity } \\
\text { from different } \\
\text { strain }\end{array}$ & In use & Zhu et al. (2020) \\
\hline
\end{tabular}


replication-deficient adenoviral vector ChAdOx1 (chimpanzee) (Voysey et al. 2021). As per reports, this vaccine has $65 \%$ efficiency against COVID-19 after 28 days of 2 dose vaccination and has shown blood clotting issues after vaccination. Due to this reason, 12 countries across the globe rejected the use of this vaccine. After the safety community confirmed the vaccine benefits more than the risks and its non-association with high risk of blood clotting, on 31 March 2021. AstraZeneca, TGA, WHO and MHRA have issued statements for the safety use and efficiency (Madhi et al. 2021). This vaccine worked against UK variants and induced antibodies were low with neutralisation. 32,000 participants participated in clinical trials (Clinical trial id NCT04516746).

Sputnik V Gamaleya research institute, A Russian Medical Research Institute of the Russian Health Ministry developed a recombinant adenovirus vaccine called Sputnik V/GamCOVID-Vac. This vaccine delivers SARS-CoV-2 spike protein using a novel heterologous recombinant adenovirus approach. This heterologous adenoviral vector has adenovirus $26(\mathrm{Ad} 26)$ and adenovirus 5 (Ad5) components (Jones et al. 2021). This vaccine is administered in two doses within 21 days and has an efficiency of $91 \%$ against SARS-CoV-2. It shows high humoral and cellular immune response along with good tolerability, immunogenicity and high efficiency, 40,000 participants participated in the clinical trials (Clinical id NCT04530396) of Sputnik V.

JNJ-78436735 JNJ-78436735 is a monovalent vaccine composed of a replication incompetent recombinant Ad26 vector that encodes SARS-CoV-2 viral spike protein. The vaccine was developed by Johnson \& Johnson, administered in two doses in 28 days' time gap, and showed $66 \%$ efficiency against COVID-19 severe conditions (Logunov et al. 2021). Rare incidences of cerebral venous sinus thrombosis was observed after taking this vaccination, US had paused the administration of the vaccine while FDA, CDC and ACIP investigated the risks. On 20 April EMA approved by saying that, thrombosis is rare and common with decreased numbers of blood platelets. The total number of clinical trial participants is 43,783 and it is an effective vaccine against moderate and severe COVID-19 in the United States (Clinical id NCT04505722).

Ad5-nCoV This vaccine is developed by China-based CanSino Biologics using adenovirus vector, Canvidicea. $\mathrm{Ad} 5-\mathrm{nCoV}$ is an Ad5 vector based (E1 and E3 deleted, replication defective) vaccine expressing the full-length spike protein of COVID19 virus (Wuhan-Hu-1 strain, YP_009724390) with the tissue plasminogen activator signal peptide gene (Zhu et al. 2020). This vaccine has an efficiency of $65 \%$ with two doses of vaccination in 21 days. In clinical trials, 40,000 participants are involved (Clinical trial id NCT04526990. After vaccination elevated IFN- $\alpha$ levels and T-cell response were observed.

\section{Peptide vaccine}

EpiVacCorona EpiVacCorona is a chemically synthesized peptide (three short fragments/epitopes of viral spike protein)-based vaccine developed by the federal budgetary and state research center of virology, Russia. These short peptides represent the immunogenic B-cell epitopes that should be recognized by the human immune system. The peptides are subsequently conjugated to a chimeric carrier protein and given as a vaccine. The vaccine showed $90 \%$ efficiency as per reports after administration of two doses in 21 days. Reports also revealed the vaccine tolerability, safety, immunogenicity against COVID-19 (Ryzhikov et al. 2021). The total 3000 study participants participated (Clinical id NCT04527575) in this clinical trial.

\section{Effective under trial vaccines}

Novavax is developing a vaccine called NVX-CoV2373 with a prefusion protein nanoparticles against COVID-19. This vaccine has the highest efficiency against COVID-19. This is under a third phase clinical trial and soon it will come into use. NVX-CoV2373 (Clinical trials id NCT04368988) induced immunogenicity and showed protective response against respiratory diseases (Poland et al. 2020; Cheryl et al. 2020; Shinde et al. 2021). Another vaccine, ZyCoV-D is a plasmid based DNA Vaccine, under phase 3 clinical trials, with approval from Drug Control General of India. It exhibited an efficient immune response. Abdala (CIGB 66), a protein-based vaccine, is under phase 3 clinical trial (Yadav et al. 2020; Ward et al. 2020). Medicago is an influenza vaccine that is under trial. When tested after 20 days, virallike particles were working against the COVID-19. Under fast track FDA approved to release vaccine for emergency use. VLA2001 is an inactivated vaccine developed with support from the UK national institute of health research. This vaccine is safer and well tolerated to neutralize antibodies in study participants (Peter et al. 2020; Cecilia et al. 2020; Smith et al. 2020; Pablo et al. 2020; Elizabeth et al. 2020; Capone et al. 2020; Richmond et al. 2021). In addition, there are about 60 vaccines under trials. Few vaccines are in phase- 3 trials and many are in phase- 1 or -2 trial shown in Table 8.

Many more vaccines are under development viz: CvnCoV, BCG, INO-4800, UB-612, GRAd-COV2, SCB-2019, Nanocovax, BNT162, Soberana1 and 2, AdCLD-CoV19, ABNCoV2, EuCorVac-19, Mambisa (CIGB-669), IIBR100, AGO301-COVID-19, GX-19N, ARCT-021-COVID-19, HGCO-19, MRT5500, AV-COVID-19, SpFN, KBP-201, 
Table 8 Vaccine Trials of SARS-CoV-2

\begin{tabular}{|c|c|c|c|c|c|c|}
\hline S. no. & Name & Ag type & Developing Countries & Trail phase & Clinical trial id & References \\
\hline 1 & $\begin{array}{l}\text { Novovax } \\
\text { NVX-CoV2373 }\end{array}$ & Nanoparticle & UK & Phase3 & $\begin{array}{l}\text { NCT04368988 } \\
\text { NCT04533399 } \\
\text { NCT04611802 }\end{array}$ & $\begin{array}{l}\text { Cheryl et al. (2020); Shinde } \\
\text { et al. (2021) }\end{array}$ \\
\hline 2 & ZyCoV-D & DNA (plasmid) & India & Phase 3 & NA & Yadav et al. (2020) \\
\hline 3 & Abdala (CIGB66) & Protein Subunit & Cuba & phase3 & NA & Zimmer et al. (2021) \\
\hline 4 & Medicago & Plant based protein/VLP & Canada & phase3 & $\begin{array}{l}\text { NCT04450004 } \\
\text { NCT04636697 }\end{array}$ & Ward et al. (2020) \\
\hline 5 & VLA2001 & Inactivated & UK & Phase3 & $\begin{array}{l}\text { NCT04671017 } \\
\text { NCT04864561 }\end{array}$ & $\begin{array}{l}\text { https://valneva.com/press- } \\
\text { release/valneva-repor } \\
\text { ts-positive-phase-1-2- } \\
\text { data-for-its-inactivated- } \\
\text { adjuvanted-covid-19-vacci } \\
\text { ne-candidate-vla2001/ }\end{array}$ \\
\hline 6 & Un named & Adjuvant protein & US, India & phase3 & NA & $\begin{array}{l}\text { http://ctri.nic.in/Clinicaltr } \\
\text { ials/pdf_generate.php? } \\
\text { trialid=48329\&EncHid= } \\
\& \text { modid=\&compid=\% } \\
\text { 27,\%2748329det } \% 27\end{array}$ \\
\hline 7 & CvnCov & mRNA based & Multinational & phase $2 b / 3$ & $\begin{array}{l}\text { NCT04449276 } \\
\text { NCT04515147 } \\
\text { NCT04652102 } \\
\text { NCT04674189 }\end{array}$ & Peter et al. (2020) \\
\hline 8 & BCG Vaccine & Live attunated & Australia & Pahse $2 / 3$ & NCT04328441 & Cecilia et al. (2020) \\
\hline 9 & INO-4800 & DNA vaccine & US & Phase $2 / 3$ & $\begin{array}{l}\text { NCT04336410 } \\
\text { NCT04447781 } \\
\text { NCT04642638 }\end{array}$ & $\begin{array}{l}\text { Smith et al. (2020); Pablo } \\
\text { et al. (2020) }\end{array}$ \\
\hline 10 & No name & Adenovirus & US & Phase $2 / 3$ & NCT04591717 & Elizabeth et al. (2020) \\
\hline 11 & UB-612 & Multi peptide & US & Phase $2 / 3$ & $\begin{array}{l}\text { NCT04545749 } \\
\text { NCT04683224 }\end{array}$ & $\begin{array}{l}\text { https://www.businesswi } \\
\text { re.com/news/home/ } \\
\text { 20210208005198/en/ } \\
\text { COVAXX\%E2\%80\%99s- } \\
\text { COVID-19-Vaccine-UB- } \\
\text { 612-Induced-Neutralizi } \\
\text { ng-Antibodies-in-100- } \\
\text { of-Participants-During- } \\
\text { Phase-1-Clinical-Trial }\end{array}$ \\
\hline 12 & GRAd-COV2 & Adenovirus & $\begin{array}{l}\text { Italy, Germany and } \\
\text { Belgium }\end{array}$ & Phase $2 / 3$ & NCT04528641 & Capone et al. (2020) \\
\hline 13 & SCB-2019 & Protein Part & China & Phase $2 / 3$ & $\begin{array}{l}\text { NCT04405908 } \\
\text { NCT04672395 }\end{array}$ & Richmond et al. (2021) \\
\hline 14 & Unname & Recombinant protein & UK & Phase2 & $\begin{array}{l}\text { NCT04537205 } \\
\text { NCT04762680 }\end{array}$ & $\begin{array}{l}\text { https://www.gsk.com/ } \\
\text { en-gb/media/press-relea } \\
\text { ses/sanofi-and-gsk-initi } \\
\text { ate-phase-12-clinical- } \\
\text { trial-of-covid-19-adjuv } \\
\text { anted-recombinant-prote } \\
\text { in-based-vaccine-candi } \\
\text { date/\# }\end{array}$ \\
\hline 15 & Soberana & Monovalent /conjugate & Cuba & Phase $1 / 2 / 3$ & $\begin{array}{l}\text { SOBERANA 01A } \\
\text { SOBERANA } 02\end{array}$ & $\begin{array}{l}\text { https://www.emerg } \\
\text { ency-live.com/health- } \\
\text { and-safety/cuba-minis } \\
\text { try-of-health-announces- } \\
\text { phase-3-for-abdala-cigb- } \\
\text { 66-and-soberana-02-its- } \\
\text { two-covid-19-vaccines/ }\end{array}$ \\
\hline 16 & AdCLD-CoV19 & Adenovirus & Korea & Phase $1 / 2 \mathrm{a}$ & NCT04666012 & $\begin{array}{l}\text { https://clinicaltrials.gov/ct2/ } \\
\text { show/NCT04666012 }\end{array}$ \\
\hline
\end{tabular}


MV-014-212, PTX-COVID19-B, COVI-VAC, CORVax12, MVA-SARS-2-S, COHO4S1, Pvac, Admir SC-2f, BACTRL-Spike, Covax-19, DelNS1-2019-nCoV RBD -OPT1, UQ-CSLV451, VXA- CoV2-1, AdCOVID, AACOVID, ChAd-SARS-CoV-2-S, HaloVax, LineaDNA, PittCoVacc, T-COVIDTM, LNP-nCoVsaRNA, V590, and V 591 along with few unnamed vaccines that are undergoing clinical trials. (https://www.raps.org/news-and-articles/news-articles/ 2020/3/covid-19-vaccine-tracker).

\section{Future perspectives}

SARS-CoV-2 viral lineage analysis and review of its genetic recombination patterns shows the SARS-CoV-2 variants that pose health threats especially to the humans. This is majorly caused by crossing of genetical regions among different SARS-CoV-2 strains that can be haphazard as different recombinant strains have diverse severing points. Though many candidate vaccines, drugs and therapies are under trial stage, keeping in view the global viral mutation frequencies, it is warranted to have a multi-therapeutic approach to effectively target COVID-19 or any other possible coronavirus infection variants. There are many more potential therapeutics including phytomedicines, that can be aimed at multiple target sites of the viral infection pathways. The use of phytomedicines in these lines cannot be ignored, since phytochemicals are proven to possess multiple targeted therapeutic approaches, with no/little side effects. Moreover, phytochemicals and herbal formulations are proved to possess antiviral properties especially against human viral infections and hence their role in effectively combating the current pandemic appears significant, which also needs urgent attention.

Acknowledgements Authors thank DST-SERB and ICMR for providing financial assistance to Dr. V. Damodara Reddy under Ramanujan Fellowship (SB/S2/RJN-043/2014) and Mrs. Swetha Pulakuntla under ICMR-SRF (ISRM/11(20/2017) schemes.

\section{Declarations}

Conflict of interest The authors declare no conflict of interest.

\section{References}

Ahn DG, Shin HJ, Kim MH, Lee S, Kim HS, Myoung J, Kim BT, Kim SJ (2020) Current status of epidemiology, diagnosis, therapeutics, and vaccines for novel coronavirus disease 2019 (COVID-19). J Microbiol Biotechnol 30(3):313-324. https://doi.org/10.4014/ jmb.2003.03011

Alijotas-Reig J, Esteve-Valverde E, Belizna C, Selva-O'Callaghan A, Pardos-Gea J, Quintana A, Mekinian A, Anunciacion-Lunell A, Miró-Mur F (2020) Immunomodulatory therapy for the management of severe COVID-19. Beyond the anti-viral therapy: a comprehensive review. Autoimmun Rev. https://doi.org/ 10.1016/j.autrev.2020.102569

Amawi H, Abu Deiab GI, Aljabali AA, Dua K, Tambuwala MM (2020) COVID-19 pandemic: an overview of epidemiology, pathogenesis, diagnostics and potential vaccines and therapeutics. Ther Deliv 11(4):245-268. https://doi.org/10.4155/tde-2020-0035

Ang L, Lee HW, Choi JY, Zhang J, Lee MS (2020) Herbal medicine and pattern identification for treating COVID-19: a rapid review of guidelines. Integr Med Res 9:100407. https://doi.org/10.1016/j. imr.2020.100407

Badri KR, Aramgam S, Muppurum MK, Kona A, Kona A (2021) Efficacy of Tinospora cordifolia in treating SARS-CoV-2: in silico studies. FASEB J 35(1):4976. https://doi.org/10.1096/fasebj.2021. 35.S1.04976

Banerjee A, Subudhi S, Rapin N, Lew J, Jain R, Falzarano D, Misra V (2020) Selection of viral variants during persistent infection of insectivorous bat cells with Middle East respiratory syndrome coronavirus. Sci Rep 10(1):7257. https://doi.org/10.1038/ s41598-020-64264-1

Capone $\mathrm{S}$ et al (2020) Immunogenicity of a new gorilla adenovirus vaccine candidate for COVID-19. bioRxiv. https://doi.org/10.1101/ 2020.10.22.349951

Cecilia $S$ et al (2020) Lack of evidence for BCG vaccine protection from severe COVID-19. NAS. 117(41):25203-25204. https://doi. org/10.1073/pnas.2016733117

Cherian S, Potdar V, Jadhav S, Yadav P, Gupta N, Das M, Rakshit P, Singh S, Abraham P, Panda S, Team N (2021) SARS-CoV-2 spike mutations, L452R, T478K, E484Q and P681R, in the Second Wave of COVID-19 in Maharashtra, India. Microorganisms 9(7):1542. https://doi.org/10.3390/microorganisms9071542

Cheryl Keech MD, Ph D, Gary Albert MS et al (2020) Phase 1-2 trial of a SARS-CoV-2 recombinant spike protein nanoparticle vaccine. N Engl J Med 383:2320-2332. https://doi.org/10.1056/ NEJMoa2026920

Corman VM, Landt O, Kaiser M, Molenkamp R, Meijer A, Chu DK, Bleicker T, Brünink S, Schneider J, Schmidt ML, Mulders DG, Haagmans BL, van der Veer B, van den Brink S, Wijsman L, Goderski G, Romette JL, Ellis J, Zambon M, Peiris M et al (2020) Detection of 2019 novel coronavirus (2019-nCoV) by real-time RT-PCR. Euro Surveill Bull Euro Surveill 25(3):2000045. https:// doi.org/10.2807/1560-7917.ES.2020.25.3.2000045

Cunningham AC, Goh HP, Koh D (2020) Treatment of COVID-19: old tricks for new challenges. Crit Care 24(1):91. https://doi.org/10. 1186/s13054-020-2818-6

Cyranoski D (2020) Profile of a killer: the complex biology powering the coronavirus pandemic. Nature 581(7806):22-26. https://doi. org/10.1038/d41586-020-01315-7

da Rosa MR, Francelino Silva Junior LC, Santos Santana FM et al (2021) Clinical manifestations of COVID-19 in the general population: systematic review. Wien Klin Wochenschr 133(7-8):377382. https://doi.org/10.1007/s00508-020-01760-4

de Groot RJ, Baker SC, Baric RS, Brown CS, Drosten C, Enjuanes L, Fouchier RA, Galiano M, Gorbalenya AE, Memish ZA, Perlman S, Poon LL, Snijder EJ, Stephens GM, Woo PC, Zaki AM, Zambon M, Ziebuhr J (2013) Middle East respiratory syndrome coronavirus (MERS-CoV): announcement of the Coronavirus Study Group. J Virol 87(14):7790-7792. https://doi.org/10.1128/ JVI.01244-13

Dong L, Hu S, Gao J (2020) Discovering drugs to treat coronavirus disease 2019 (COVID-19). Drug Discov Ther 14(1):58-60. https:// doi.org/10.5582/ddt.2020.01012

Doroftei B, Ciobica A, Ilie OD, Maftei R, Ilea C (2021) Mini-review discussing the reliability and efficiency of COVID-19 vaccines. Diagnostics (basel, Switzerland) 11(4):579. https://doi.org/10. 3390/diagnostics 11040579 
Du HZ, Hou XY, Miao YH, Huang BS, Liu DH (2020) Traditional Chinese Medicine: an effective treatment for 2019 novel coronavirus pneumonia (NCP). Chin J Nat Med 18(3):206-210. https:// doi.org/10.1016/S1875-5364(20)30022-4

Elizabeth $\mathrm{G}$ et al (2020) Complete protection of nasal and lung airways against SARS-CoV-2 challenge by antibody plus Th1 dominant $\mathrm{N}$ - and S-Specific T-Cell responses to subcutaneous prime and thermally-stable oral boost bivalent hAd5 vaccination in an NHP study. bioRxiv. https://doi.org/10.1101/2020. 12.08.416297

Ella R, Vadrevu KM, Jogdand H, Prasad H et al (2021) Safety and immunogenicity of an inactivated SARS-CoV-2 vaccine, BBV152: a double-blind, randomised, phase 1 trial. Lancet Infect Dis 5:637-646. https://doi.org/10.1016/S1473-3099(20)30942-7

Gautret P, Lagier JC, Parola P, Hoang VT, Meddeb L, Mailhe M, Doudier B, Courjon J, Giordanengo V, Vieira VE, Tissot Dupont H, Honoré S, Colson P, Chabrière E, La Scola B, Rolain JM, Brouqui P, Raoult D (2020) Hydroxychloroquine and azithromycin as a treatment of COVID-19: results of an open-label non-randomized clinical trial. Int J Antimicrob Agents 56(1):105949. https://doi. org/10.1016/j.ijantimicag.2020.105949

Girija PLT, Sivan N (2020) Ayurvedic treatment of COVID-19/ SARS-CoV-2: a case report. J Ayurveda Integr Med. 19:S09759476(20)30042-5. https://doi.org/10.1016/j.jaim.2020.06.001

Gorbalenya AE, Baker SC, Baric RS, de Groot RJ, Drosten C, Gulyaeva AA, Haagmans BL, Lauber C, Leontovich AM, Neuman BW, Penzar D (2020) The species severe acute respiratory syndrome related coronavirus: classifying $2019-\mathrm{nCoV}$ and naming it SARS-CoV-2. Nat Microbiol 5:536-544. https://doi.org/10.1038/ s41564-020-0695-z

Gorbalenya AE, Siddell SG (2021) Recognizing species as a new focus of virus research. PLoS Pathog. https://doi.org/10.1371/journal. ppat. 1009318

Horby P, Lim WS, Emberson JR, Mafham M, Bell JL, Linsell L, Staplin N, Brightling C, Ustianowski A, Elmahi E, Prudon B, Green C, Felton T, Chadwick D, Rege K, Fegan C, Chappell LC, Faust SN, Jaki T et al (2021) Dexamethasone in hospitalized patients with covid-19. N Engl J Med 384(8):693-704. https://doi.org/10. 1056/NEJMoa2021436

Jones I, Roy P (2021) Sputnik V COVID-19 vaccine candidate appears safe and effective. Lancet 397(10275):642-643. https://doi.org/10. 1016/S0140-6736(21)00191-4

Kalil AC (2020) Treating COVID-19—off-label drug use, compassionate use, and randomized clinical trials during pandemics. JAMA 323(19):1897-1898. https://doi.org/10.1001/jama.2020.4742

Kim JS, Jang JH, Kim JM, Chung YS, Yoo CK, Han MG (2020) Genome-wide identification and characterization of point mutations in the SARS-CoV-2 genome. Osong Public Health Res Perspect 11(3):101-111. https://doi.org/10.24171/j.phrp.2020.11.3. 05

Koyama T, Platt D, Parida L (2020) Variant analysis of SARS-CoV-2 genomes. Bull World Health Organ 98(7):495-504. https://doi. org/10.2471/BLT.20.253591

Kremsner P et al (2020) Phase 1 assessment of the safety and immunogenicity of an mRNA- lipid nanoparticle vaccine candidate against SARS-CoV-2 in human volunteers. MedRxiv. https://doi.org/10. 1101/2020.11.09.20228551

Lai CC, Shih TP, Ko WC, Tang HJ, Hsueh PR (2020) Severe acute respiratory syndrome coronavirus 2 (SARS-CoV-2) and coronavirus disease-2019 (COVID-19): the epidemic and the challenges. Int J Antimicrob Agents 55(3):105924. https://doi.org/10.1016/j.ijant imicag.2020.105924

Leao JC, Gusmao T, Zarzar AM, Leao Filho JC, Santos B, de Faria A, Morais Silva IH, Gueiros L, Robinson NA, Porter S, Carvalho A (2020) Coronaviridae-Old friends, new enemy! Oral Dis. https:// doi.org/10.1111/odi.13447
Li Q, Wu J, Nie J, Zhang L, Hao H, Liu S, Zhao C, Zhang Q, Liu H, Nie L, Qin H, Wang M, Lu Q, Li X, Sun Q, Liu J, Zhang L, Li X, Huang W, Wang Y (2020) The impact of mutations in SARS-CoV-2 spike on viral infectivity and antigenicity. Cell 182(5):1284-1294.e9. https://doi.org/10.1016/j.cell.2020.07.012

Liu Y, Gayle AA, Wilder-Smith A, Rocklöv J (2020) The reproductive number of COVID-19 is higher compared to SARS coronavirus. J Travel Med 27(2):taaa021. https://doi.org/10.1093/jtm/taaa021

Logunov DY, Dolzhikova IV et al (2021) (2021) Safety and efficacy of an rAd26 and rAd5 vector-based heterologous prime-boost COVID-19 vaccine: an interim analysis of a randomised controlled phase 3 trial in Russia. Lancet 397(10275):671-681. https://doi.org/10.1016/S0140-6736(21)00234-8

Luo H, Tang QL, Shang YX, Liang SB, Yang M, Robinson N, Liu JP (2020) Can Chinese Medicine Be Used for Prevention of Corona Virus Disease 2019 (COVID-19)? A review of historical classics, research evidence and current prevention programs. Chin J Integr Med 26(4):243-250. https://doi.org/10.1007/s11655-020-3192-6

Madhi SA, Baillie V, Cutland CL et al (2021) Efficacy of the ChAdOx1 nCoV-19 Covid-19 vaccine against the B.1.351 variant. N Engl J Med 384(20):1885-1898. https://doi.org/10.1056/NEJMoa2102 214

Maitra A, Sarkar MC, Raheja H, Biswas NK, Chakraborti S, Singh AK, Ghosh S, Sarkar S, Patra S, Mondal RK, Ghosh T, Chatterjee A, Banu H, Majumdar A, Chinnaswamy S, Srinivasan N, Dutta S, Das S (2020) Mutations in SARS-CoV-2 viral RNA identified in Eastern India: possible implications for the ongoing outbreak in India and impact on viral structure and host susceptibility. J Biosci 45(1):76. https://doi.org/10.1007/s12038-020-00046-1

McKee DL, Sternberg A, Stange U, Laufer S, Naujokat C (2020) Candidate drugs against SARS-CoV-2 and COVID-19. Pharmacol Res 157:104859. https://doi.org/10.1016/j.phrs.2020.104859

Mercatelli D, Giorgi FM (2020) Geographic and genomic distribution of SARS-CoV-2 mutations. Front Microbiol 11:1800. https://doi. org/10.3389/fmicb.2020.01800

Ni L, Ye F, Cheng ML, Feng Y, Deng YQ, Zhao H, Wei P, Ge J, Gou M, Li X, Sun L, Cao T, Wang P, Zhou C, Zhang R, Liang P, Guo H, Wang X, Qin CF, Chen F, Dong C (2020) Detection of SARS-CoV-2-specific humoral and cellular immunity in COVID19 convalescent individuals. Immunity 52(6):971-977.e3. https:// doi.org/10.1016/j.immuni.2020.04.023

Pablo T et al (2020) Safety and immunogenicity of INO-4800 DNA vaccine againstSARS-CoV-2: a preliminary report of an openlabel, Phase 1 clinical trial. Eclin Med 31(2021):100689. https:// doi.org/10.1016/j.eclinm.2020.100689

Pascarella G, Strumia A, Piliego C, Bruno F, Del Buono R, Costa F, Scarlata S, Agrò FE (2020) COVID-19 diagnosis and management: a comprehensive review. J Intern Med 288(2):192-206. https://doi.org/10.1111/joim.13091

Planas D, Veyer D, Baidaliuk A et al (2021) Reduced sensitivity of SARS-CoV-2 variant Delta to antibody neutralization. Nature 596(7871):276-280. https://doi.org/10.1038/s41586-021-03777-9

Polack FP, Thomas SJ, Kitchin N, Absalon J, Gurtman A, Lockhart S, Perez JL, Pérez Marc G, Moreira ED, Zerbini C, Bailey R (2020) Safety and efficacy of the BNT162b2 mRNA Covid-19 vaccine. N Engl J Med 383(27):2603-2615. https://doi.org/10.1056/NEJMo a2034577

Poland GA, Ovsyannikova IG, Kennedy RB (2020) SARS-CoV-2 immunity: review and applications to phase 3 vaccine candidates. Lancet 396(10262):1595-1606. https://doi.org/10.1016/S01406736(20)32137-1

Pulakuntla S, Lokhande KB, Padmavathi P et al (2021) Mutational analysis in international isolates and drug repurposing against SARS-CoV-2 spike protein: molecular docking and simulation approach. VirusDis. https://doi.org/10.1007/s13337-021-00720-4 
Rahman MS, Hoque MN, Islam MR, Islam I, Mishu ID, Rahaman MM, Sultana M, Hossain MA (2021) Mutational insights into the envelope protein of SARS-CoV-2. Gene Rep 22:100997. https:// doi.org/10.1016/j.genrep.2020.100997

Ren JL, Zhang AH, Wang XJ (2020) Traditional Chinese medicine for COVID-19 treatment. Pharmacol Res 155:104743. https://doi.org/ 10.1016/j.phrs.2020.104743

Richmond P, Hatchuel L, Dong M, Ma B, Hu B, Smolenov I, Li P, Liang P, Han HH, Liang J, Clemens R (2021) Safety and immunogenicity of S-Trimer (SCB-2019), a protein subunit vaccine candidate for COVID-19 in healthy adults: a phase 1, randomised, double-blind, placebo-controlled trial. Lancet 397(10275):682694. https://doi.org/10.1016/S0140-6736(21)00241-5

Ryzhikov AB, Ryzhikov EA, Bogryantseva MP, Danilenko ED, Imatdinov IR, Nechaeva EA et al (2021) Immunogenicity and protectivity of the peptide vaccine against SARS-CoV-2. Ann Russian Acad Med Sci 76(1):5-19. https://doi.org/10.15690/vramn1528

Sadoff J, Gray G, Vandebosch A et al (2021) Safety and efficacy of single-dose Ad26.COV2.S vaccine against Covid-19. N Engl J Med. https://doi.org/10.1056/NEJMoa2101544

Sheahan TP, Sims AC, Leist SR et al (2020) Comparative therapeutic efficacy of remdesivir and combination lopinavir, ritonavir, and interferon beta against MERS-CoV. Nat Commun 11:222. https:// doi.org/10.1038/s41467-019-13940-6

Shen C, Wang Z, Zhao F, Yang Y, Li J, Yuan J, Wang F, Li D, Yang M, Xing L, Wei J (2020) Treatment of 5 critically ill patients with COVID-19 with convalescent plasma. JAMA 323(16):1582-1589. https://doi.org/10.1001/jama.2020.4783

Shen L, Bard JD, Triche TJ, Judkins AR, Biegel JA, Gai X (2021) Emerging variants of concern in SARS-CoV-2 membrane protein: a highly conserved target with potential pathological and therapeutic implications. Emerg Microbes Infect 10(1):885-893. https://doi.org/10.1080/22221751.2021.1922097

Shinde V, Bhikha S, Hoosain Z, Archary M, Bhorat Q, Fairlie L, Lalloo U, Masilela M, Moodley D, Hanley S, Fouche L, Louw C, Tameris M, Singh N, Goga A, Dheda K, Grobbelaar C, Kruger G, Carrim-Ganey N, Baillie V et al (2021) Efficacy of NVX-CoV2373 Covid-19 Vaccine against the B.1.351 Variant. N Engl J Med 384(20):1899-1909. https://doi.org/10.1056/NEJMoa2103055

Shree P, Mishra P, Selvaraj C, Singh SK, Chaube R, Garg N, Tripathi YB (2020) Targeting COVID-19 (SARS-CoV-2) main protease through active phytochemicals of ayurvedic medicinal plantsWithania somnifera (Ashwagandha), Tinospora cordifolia (Giloy) and Ocimum sanctum (Tulsi) - a molecular docking study. J Biomol Struct Dyn 27:1-14. https://doi.org/10.1080/07391102.2020. 1810778

Smith TRF, Patel A, Ramos S et al (2020) Immunogenicity of a DNA vaccine candidate for COVID-19. Nat Commun 11:2601. https:// doi.org/10.1038/s41467-020-16505-0

Stebbing J, Phelan A, Griffin I, Tucker C, Oechsle O, Smith D, Richardson P (2020) COVID-19: combining antiviral and anti-inflammatory treatments. Lancet Infect Dis 20(4):400-402. https://doi. org/10.1016/S1473-3099(20)30132-8

Tang D, Comish P, Kang R (2020) The hallmarks of COVID-19 disease. PLoS Pathog 16(5):e1008536. https://doi.org/10.1371/journ al.ppat.1008536

Tanriover MD, Doğanay HL, Akova M, Güner HR, Azap A, Akhan S, Köse Ş, Erdinç FŞ, Akalın EH, Tabak ÖF, Pullukçu H, Batum Ö, Şimşek Yavuz S, Turhan Ö, Yıldırmak MT, Köksal İ, Taşova Y, Korten V, Yılmaz G, Çelen MK et al (2021) Efficacy and safety of an inactivated whole-virion SARS-CoV-2 vaccine (CoronaVac): interim results of a double-blind, randomised, placebocontrolled, phase 3 trial in Turkey. Lancet (london, England) 398(10296):213-222. https://doi.org/10.1016/S0140-6736(21) 01429-X
Thomas S (2020) The structure of the membrane protein of SARSCoV-2 resembles the sugar transporter SemiSWEET. Pathog Immunity 5(1):342-363. https://doi.org/10.20411/pai.v5i1.377

Vahey GM, Marshall KE, McDonald E, Martin SW et al (2020) Symptom profiles and progression in hospitalized and nonhospitalized patients with coronavirus disease, Colorado, USA. Emerg Infect Dis 27(2):385-395. https://doi.org/10.3201/eid2702.203729

Verma A, Adhikary A, Woloschak G, Dwarakanath BS, Papineni RVL (2020) A combinatorial approach of a polypharmacological adjuvant 2-deoxy-D-glucose with low dose radiation therapy to quell the cytokine storm in COVID-19 management. Int J Radiat Bio 96(11):1323-1328. https://doi.org/10.1080/09553002.2020. 1818865

Voysey M, Clemens S, Madhi SA, Weckx LY, Folegatti PM, Aley PK, Angus B, Baillie VL, Barnabas SL, Bhorat QE, Bibi S, Briner C, Cicconi P, Collins AM, Colin-Jones R, Cutland CL, Darton TC, Dheda K, Duncan C, Emary K et al (2021) Safety and efficacy of the ChAdOx1 nCoV-19 vaccine (AZD1222) against SARSCoV-2: an interim analysis of four randomised controlled trials in Brazil, South Africa, and the UK. Lancet 397(10269):99-111. https://doi.org/10.1016/S0140-6736(20)32661-1

Wang H, Zhang Y, Huang B, Deng W, Quan Y, Wang W, Xu W, Zhao Y, Li N, Zhang J, Liang H, Bao L, Xu Y, Ding L, Zhou W, Gao H, Liu J, Niu P, Zhao L, Zhen W et al (2020) Development of an inactivated vaccine candidate, BBIBP-CorV, with potent protection against SARS-CoV-2. Cell 182(3):713-721.e9. https://doi. org/10.1016/j.cell.2020.06.008

Wang GL, Wang ZY, Duan LJ, Meng QC, Jiang MD, Cao J, Yao L, Zhu KL, Cao WC, Ma MJ (2021) Susceptibility of circulating SARS$\mathrm{CoV}-2$ variants to neutralization. N Engl J Med 6:NEJMc2103022. https://doi.org/10.1056/NEJMc2103022

Ward BJ et al (2020) Phase 1 trial of a candidate recombinant viruslike particle vaccine for Covid-19 disease produced in plants. MedRxiv. https://doi.org/10.1101/2020.11.04.20226282

Wu A, Peng Y, Huang B, Ding X, Wang X, Niu P, Meng J, Zhu Z, Zhang Z, Wang J, Sheng J, Quan L, Xia Z, Tan W, Cheng G, Jiang T (2020) Genome composition and divergence of the novel coronavirus (2019-nCoV) originating in China. Cell Host Microbe 27(3):325-328. https://doi.org/10.1016/j.chom.2020.02.001

Wu K, Werner et al (2021) Serum neutralizing activity elicited by mRNA-1273 vaccine. N Engl J Med 384(15):1468-1470. https:// doi.org/10.1056/NEJMc2102179

Yadav PD et al (2020) Assessment of immunogenicity and protective efficacy of ZyCoV-D DNA vaccine candidates in Rhesus macaques against SARS-CoV-2 infection. bioRxiv. https://doi. org/10.1101/2021.02.02.429480

Yang X, Dong N, Chan EW-C, Chen S (2020) Genetic cluster analysis of SARS-CoV-2 and the identification of those responsible for the major outbreaks in various countries. Emerg Microbes Infect 9(1):1287-1299. https://doi.org/10.1080/22221751.2020.1773745

Zhou P, Yang XL, Wang XG, Hu B, Zhang L, Zhang W et al (2020) A pneumonia outbreak associated with a new coronavirus of probable bat origin. Nature 579(7798):270-273. https://doi.org/10. 1038/s41586-020-2951.z

Zhu FC, Li YH, Guan XH et al (2020) Safety, tolerability, and immunogenicity of a recombinant adenovirus type- 5 vectored COVID-19 vaccine: a dose-escalation, open-label, non-randomised, first-inhuman trial. Lancet 395(10240):1845-1854. https://doi.org/10. 1016/S0140-6736(20)31208-3

Zimmer C, Corum J, Wee SL (2021) Coronavirus vaccine tracker. The New York Times (ISSN 0362-4331)

Publisher's Note Springer Nature remains neutral with regard to jurisdictional claims in published maps and institutional affiliations. 